\title{
Gender Poverty Gap: A Comparative analysis of India and Pakistan
}

\author{
Muhammmad Siddique ${ }^{a}$, Misbah Nosheen ${ }^{b}$ \\ ${ }^{\text {a }}$ PhD scholar, Department of economics, Hazara University Mansehra, KPK, Pakistan \\ Email: siddique63@yahoo.com \\ ${ }^{\mathrm{b}}$ HOD, Department of economics, Hazara University Mansehra, KPK, Pakistan \\ Email: misbah_nosheen@yahoo.com
}

\begin{tabular}{ll}
\hline ARTICLE DETAILS & ABSTRACT \\
\hline History: & This paper attempts to estimate gender poverty gap in Pakistan using \\
Accepted 25 May 2021 & multidimensional poverty approach and compares it with India. \\
Available Online June 2021 & Pakistan data have been used to compute multidimensional poverty. \\
& Findings of the paper suggest that there is gender poverty gap in \\
\hline Keywords: & Pakistan. Both India and Pakistan are suffering from poverty. Head \\
Multidimensional Poverty; & count poverty is high in both countries but India has managed to lift \\
gender Poverty, Deprivation; & more people out of multidimensional poverty. The paper recommends to \\
Pakistan; India & design targeted oriented policies reduce gender poverty.
\end{tabular}

JEL Classification:

I130, I32

DOI: $10.47067 /$ reads.v7i2.364

(C) 2021 The authors. Published by SPCRD Global Publishing. This is an open access article under the Creative Commons Attribution-

NonCommercial 4.0

Corresponding author's email address: siddique63@yahoo.com

\section{Introduction}

Poverty is common, globalized curse and unique syndrome (Chosal, 2008). World community is belligerent against tenacious poverty. Process of reduction in poverty is lukewarm despite titanic measures taken by countries individually and by international agencies. Gender poverty is even more pervasive and persevered. According to Bureau of International Information Program, United States Department of State (2017), women of the developing world face poverty disproportionately. Picture of poverty is seen even bleak if one views it through the lens of multidimensional poverty. Unidimensional poverty does not cover the viscosity of deprivation suffered by poor segment of society. On the other hand, multidimensional poverty takes into account several overlapping deprivations experienced by poor people. Just like the speed of light which changes as medium through which its travels changes, scenario of poverty changes as we move from money - metric measure of poverty to multidimensional poverty -measure. According to Alkire and Jahan (2018), "for multiple overlapping deprivations the global Multidimensional Poverty Index (MPI) is suitable measure”. 
Review of Economics and Development Studies, Vol. 7 (2) 2021, 287 - 298

Umpteen empirical studies on multidimensional poverty considered household as a unit of identification (Rogan, 2016a; Klasen and Lahoti, 2016)1. Multidimensional approach for poverty suffers from some weakness. This approach assumes that all members of a household are considered multidimensional poor if household is identified as poor (Klasen and Lahoti, 2016). Women particularly in a household face inequality. They have no or limited access to economic resources. They are predominantly engaged in household caring jobs. Globally, unpaid domestic work is disproportionately carried out by female. Women, on average, spend two to ten time more time than their counterpart on domestic care work, left with insufficient time for personal care, leisure, paid work and other social and political activities (Karimli et al, 2016). In many developing nations women accept their role as unpaid domestic workers a divine right. In some Muslim societies women consider it a sin to question the authority of man. Notably, if a women in a household is not poor even then she is more vulnerable to poverty. An endoscopic examination of poverty is needed for exploratory diagnostic of intra - household disparity and female and male contribution of gender gap in poverty.

Countries like Pakistan and India use to invest far less on women workers than working me although women appear to be productive than men, In India poor families particularly depends on the earning of the women for their survival (World Bank, 2016). Both countries enviably manage to reduce poverty particularly multidimensional poverty during last two decades. About 270 million people in India moved out multidimensional poverty between 2006/o6 to 2015/16 (UNDP; 2020).

Gender analysis of poverty could not make it place in Multidimensional poverty critique. Multidimensional poverty Index developed by Alkire and Foster (2011) is based on household's deprivation on three dimensions - education, health and standard of living. Since MPI is calculated from information from each household, so it is possible to consider the deprivations of male and female separately. Household survey data provides information regarding the characteristics of both male and female living in respective households. In order to find the gender gap in poverty, data can be decomposed according to male and female headed households and separate regressions can be carried for these sub groups to estimate the gender poverty gap (Lastrapes \& Rajaram, 2016). The present study endeavors to estimate the gender poverty gap using money - metric and multidimensional approaches by decomposing the data into male and female household heads. No previous study arguably undertook gender dimension of poverty using both money and multidimensional approaches in Pakistan. This study may contribute significantly in enhancing the understanding regarding the gender aspect of poverty and hence, may facilitate in targeting gender poverty in Pakistan.

\section{Literature Review}

After introduction of capability approach by Sen (1976), the accent pf poverty debate has shifted from unidimensional poverty to multidimensional poverty which covers various dimensions of deprivation. Since then various approaches to estimate poverty incorporating different dimensions have been proposed. Cerioli and Zani (1990) were first to suggest a Fuzzy approach which include seven dimensions of deprivation. Cheli and Lemmi (1995) modified the Fuzzy approach and proposed a new approach called Totally Fuzzy and Relative (TFR) approach to estimate multidimensional poverty. Both approaches failed to mustered considerable support due to arbitrary aggregation adopted by these approaches.

A flexible approach was proposed by Alkire and Foster in 2007 which includes three dimensions - education, health and standard of living, education has two in indicators which include year of

1 Espinoza - Delgado and Klasen (2017) used I individual - based approach to multidimensional poverty for Nicaragua. 
Review of Economics and Development Studies, Vol. 7 (2) 2021, 287 - 298

schooling and school attendance. Nutrition and Child mortality are the indicators of heath. Standard of living contains six indicators - Access to drinking water, improved sanitation, cooking fuel, type of floor of house of household, availability of electricity, Asset owned by household and fuel. This approach received tremendous support as being more dynamic and flexible. An index known as Multidimensional Poverty Index (MPI) was developed by Alkire and Santos (2007) which is very simple and easy to understand. This index is also decomposable into subgroup. The UNDP collaborated with Oxford Poverty and Development Initiative developed first global MPI in 2010 for UNDP flagship publication Human Development Report. Since then it is updated regularly to include newly released data. Globally, this index is used to compute multidimensional poverty head count and intensity both for individual countries and group of developing countries. Researches rigorously used this approach to have a clear picture of poverty. Among notable studies which used AF methodology are Batana (2008) for Sub - Saharan countries, Jamal and Harron (2007), Naveed and Islam (2010), Maqsood et al (2012) for Pakistan, Battiston et al for Latine America, Angulo et al (2003) for Colombia.

Literature on multidimensional poverty is growing momentously. Multidimensional poverty approach gained currency in recent years as being innovative and much representative. It covers broad dimensions of deprivation of poor. Supporters of multidimensional poverty are of the view that unidimensional poverty is not good measure of poverty. It covers just one dimension, that is, income. Unidimensional poverty takes a household into account as a unit of measurement thus ignoring intra household disparities. So, this approach is gender blind. It is silent on resource allocation within the household. Multidimensional measure of poverty removes this deficiency. Multidimensional poverty is broader phenomenon. "The poverty is multidimensional phenomenon" (Atkinson, 2003). "Multidimensional poverty is capable of capturing key dimensions of deprivation such as health, housing, education, schooling, and standard of livings (Chravarty, 2003; Thornbeck, 2008). These were the big reasons that the poverty paradigm has shifted from a unidimensional to multidimensional approach" (Lugo, 2016). A handsome body of literature is present on multidimensional poverty explaining the vulnerability of female. Some popular approaches have been introducing for the measurement of multidimensional poverty. Methodology which gained respectable appreciation in the literature is one proposed by Alkire and Foster $(2007,2011)$. The approach has been further refined by Alkire et, al (2015).

Individual level poverty has been conducted by Vijaya et al (2005) identifying gender difference in poverty in Indian city of Karnataka. Concept of Multidimensional poverty received tremendous popularity in social scientists as being useful tool for policy makers. Seeing the importance of the phenomenon of multidimensional, a group of researchers especially OPHI took the responsibility to grill this measure of poverty. Brandolini (2008) conducted a study estimating multidimensional poverty for Italy, France, Germany and Britain kingdom.

Kabubu et al (2010) estimated the 'multidimensional poverty in Kenya.. Jamal (2009) worked on multidimensional for Pakistan. Results of the study are summarized, "In 2004-05, 54 percent of the population were multidimensional poor". The paper further divulged, "In urban areas the extent of multidimensional poverty is less than in rural areas. In rural areas 69 percent were poor than in urban areas 21 percent people".

Calvi (2016) found that poverty in women increased with age and intra-household inequalities were more pronounced in India. Gender poverty gap was not visible when household data is used but it was palpable when individual level data was used. 
Review of Economics and Development Studies, Vol. 7 (2) 2021, 287 - 298

Lastrapes and Rajaram (2016) took new area of poverty and investigated effects of gender and social caste on penury in India for the period 2005-06. The paper used measures of household wealth from the National Family Health Survey (NFHS) of India. The paper used asset-based measures of poverty which were quite different from official measures. Official measures of India are based on consumption expenditures. However, main focus of the study was gender poverty and paper sorted data for head of families both for male and female. Logistic estimation results revealed that female-headed households generally and households belonging to marginalized social classes particularly were more likely to be poor than their counterparts. Marginalized social class was found to be more strongly associated with poverty. Whereas the gender of the household head is associated with poverty but not so robustly as marginalized social class.

Crawford et al (2017) examined gender dimension of multidimensionality of poverty in Fiji covering environment, health and unpaid [ work dimension. Findings of the study revealed that about $91 \%$ of women and $65 \&$ of men were reported to be exposed to fumes related to cooking and heating. Women and men respectively on average were exposed to one hour and 45 minutes per day of perfumes related cooking and heating. Women suffered twice as more health problem as men linked to unclean cooking and heating fuel (25 percent of 12 percent). Female were more likelihood than male to be severely deprived and very deprived in raising their voice. Primary responsibility for water fetching in Fiji rests with women. Moreover, women were more than double likely than men to report no control over personal decision (5 percent of 1.4 percent).

Lasimbo et al (2017) analyzed empirically multidimensional welfare deprivation of women in rural and urban South-South (SS) Nigeria using secondary data from Nigeria Demographic Health Survey (NDHS, 2013). Sample consisted of 1965 women from

Alkire and Kanagaratnam (2018) computed global multidimensional index for 105 developing countries which constitute about 75 percent of world's population which covers approximately 5.7 billion people. Some new indicators have been incorporated. Child stunting and age - specific Body Mass Index (BMI) cutoffs have been included in health dimension. A new indicator namely "child deaths within the 5 years period preceding the survey" was considered in health dimension.

Tekgue and Akbulut,(2019) calculated multidimensional poverty in Turkey in four equally weighted dimensions using Survey of Living Conditions during 2006-15. The study used health, education level, employment status and household living conditions as indicators of the multidimensional poverty. Findings of the study suggested that employment led to faster reduction in gender poverty. Older individuals were vulnerable to poverty. Young cohort improved. The paper concluded that gender poverty gap existed in Turkey.

\section{Methodology}

The present study employs Alkire and Kanagaratnam (2018) methodology to compute multidimensional poverty index for Pakistan using Household Integrated Income and Expenditure Survey (2015 -16). Alkire and Kanagaratnam (2018) methodology is the latest description of Alkire and Foster (2010) methodology which is continuously being updated for newly released data. A brief description of the dimensions, indicators and cutoff point for each dimension is illustrated in following table. 
Review of Economics and Development Studies, Vol. 7 (2) 2021, 287 - 298

Table (1) Cutoff Point for each Dimension

\begin{tabular}{|c|c|c|c|}
\hline Dimension & Indicator & Deprived if & Not- Deprived if \\
\hline & Read/ write & Can't read/write & Can read / write \\
\hline \multirow[t]{3}{*}{ Education } & & $\begin{array}{l}\text { Can't conduct } \\
\text { arithmetic operation }\end{array}$ & $\begin{array}{l}\text { Can conduct arithmetic } \\
\text { operation }\end{array}$ \\
\hline & Year of schooling & $\begin{array}{l}<\text { than } 6 \text { years of } \\
\text { schooling }\end{array}$ & $\geq$ years of schooling \\
\hline & $\mathrm{BHU}$ & $\begin{array}{l}\text { Does not visit at all, } \\
\text { once a while }\end{array}$ & Always visit \\
\hline \multirow[t]{3}{*}{ Health } & Water source & $\begin{array}{l}\text { Open well, river, } \\
\text { stream, ponds, other }\end{array}$ & $\begin{array}{l}\text { Tanker truck, water fetcher, } \\
\text { water motor, covered well, } \\
\text { mineral water, water tap, hand } \\
\text { pump }\end{array}$ \\
\hline & Residential status & $\begin{array}{l}\text { On rent, subsidized } \\
\text { Rent }\end{array}$ & $\begin{array}{l}\text { Personal residence, (self-hired, } \\
\text { hired), without rent }\end{array}$ \\
\hline & Energy source & $\begin{array}{l}\text { Candle, firewood, } \\
\text { other }\end{array}$ & Electricity, gas, kerosene oil \\
\hline \multirow[t]{4}{*}{ Standard of Living } & Types of roof & $\begin{array}{l}\text { Wood/bamboo, } \\
\text { other }\end{array}$ & $\mathrm{Rec} / \mathrm{BRC}$ \\
\hline & Types of toilet & $\begin{array}{l}\text { Facility not available } \\
\text { (linked to open } \\
\text { drain) other }\end{array}$ & $\begin{array}{l}\text { Privy seat, flush (linked to } \\
\text { septic tank) }\end{array}$ \\
\hline & Cooking fuel & $\begin{array}{l}\text { Fire-wood, sticks } \\
\text { etc. cow dunk, cakes } \\
\text { coal, wooden coal, } \\
\text { other }\end{array}$ & Electricity, gas, kerosene oil \\
\hline & Assets & $\begin{array}{l}\text { Does not possess TV, } \\
\text { AC }\end{array}$ & $\begin{array}{l}\text { Does possess all } \\
\text { Refrigerator, sewing machine, } \\
\text { assets, washing machine, motor } \\
\text { cycle, car }\end{array}$ \\
\hline
\end{tabular}

Own calculation based on AL Methodology (2018)

\section{Multidimensional Poverty Measurement}

Following steps are involved in Alkire and Foster methodology.

- Dual cut-off identification which identifies poor from non- poor. Dual cut - off implies deprivation cut off and poverty cut - off between poor and non- poor. This describes which person is deprived in an indicator and whether that person is deprived enough to be considered poor.

- Calculating the headcount ratio of multidimensional poverty, H. Proportion of poor people.

- Calculating the intensity of multidimensional poverty, A. Average deprivation shared by poor.

- Calculating the $\mathrm{M}_{\mathrm{o}}$ which is:

$$
\mathrm{M}_{\mathrm{o}}=\mathrm{H}^{*} \mathrm{~A}
$$




\section{Multidimensional Poverty, National Results}

In the table (1) national results of multidimensional poverty are reported. These results have been generated using Demographic Health Survey (DHS) 2013 -14 survey data. Since Household Integrated Icome and Consumption Survey (HIICS) 2015 -16survey was conducted for rebasing purpose by combining two data sets, Household Integrated Economic Survey (HIES) and Federal Bureau of Statistics (FBS). Since health section is not reported in HIICS $2015-16$, therefore, DHS survey data for $2013-14$ has been used for estimating national and provincial multidimensional poverty.

Table 2 MPI, National Results

\begin{tabular}{|l|l|l|l|l|l|}
\hline & & Coefficient & Std. Error & (95\% C.I) & \\
\hline & H & 0.40 & 0.006 & 0.774 & 0.774 \\
\hline Main & Mo & 0.208 & 0.004 & 0.464 & 0.480 \\
\hline Additional & & 0.52 & 0.002 & 0.613 & 0.623 \\
\hline
\end{tabular}

Results are based on statistical package STATA

Results shown in table (2) suggest that head count for Pakistan is 40 percent and intensity is 52.0 percent. Multidimensional poverty index is 20.8 percent. This means that in Pakistan almost 21 percent people experienced deprivation in all dimensions. This is worth noting that MPI varies at different cutoff level. Higher the cutoff point lower is the multidimensional poverty index.

\section{Decomposition by Region}

Table (3) MPI by Region

\begin{tabular}{|l|l|l|l|l|l|l|l|}
\hline & Baluchistan & Islamabad & KPK & GB & Punjab & Sindh & Total \\
\hline $\mathrm{H}$ & 0.60 & 0.813 & 0.661 & 0.673 & 0.714 & 0.56 & 0.663 \\
\hline $\mathrm{M}_{\mathrm{o}}$ & 0.29 & 0.56 & 0.350 & 0.36 & 0.411 & 0.364 & 0.364 \\
\hline Pop & 0.177 & 0.059 & 0.192 & 0.105 & 0.256 & 0.211 & 1.00 \\
\hline
\end{tabular}

Indices by subgroup (absolute)

Table(4) Aggregate

\begin{tabular}{|l|l|l|l|l|l|l|l|}
\hline & Baluchistan & Islamabad & KPK & GB & Punjab & Sindh & Total \\
\hline $\mathrm{H}$ & 0.162 & 0.075 & $0-191$ & 0.107 & 0.814 & 0.272 & 0.193 \\
\hline $\mathrm{M}_{\mathrm{o}}$ & 0.153 & 0.087 & 0.183 & 0.0 .093 & 0.511 & 0.278 & 0.207 \\
\hline
\end{tabular}

Contribution of subgroup to indices

\section{Gender Analysis of Multidimensional Poverty}

After calculating national multidimensional poverty index gender analysis of multidimensional poverty is accomplished. There are 3535 household heads of which 3287 are male and 248 are female headed households. Only 3027 observations are available for male headed households because of missing values and 224 female headed households are included for analysis. 
Review of Economics and Development Studies, Vol. 7 (2) 2021, 287 - 298

\section{Multidimensional Poverty of Female Population}

Table (5) MPI Female Member of Household

\begin{tabular}{|l|l|l|l|l|}
\hline & Coefficient & St. Error & $95 \%$ C. I & \\
\hline H & 0.219 & 0.004 & 0.211 & 0.226 \\
\hline MO & 0.21 & 0.003 & 0.181 & 0.194 \\
\hline A & 0.958 & 0.001 & 0.856 & 0.860 \\
\hline
\end{tabular}

Calculations are based on statistical Software STATA

It is apparent from the results shown in the table (5) that multidimensional poverty index is 0.188 which lower than overall MPI index. Next, MPI for male population is calculated.

\section{Multidimensional Poverty for Male Population}

Table (6) MPI for Male Population

\begin{tabular}{|l|l|l|l|l|}
\hline & Coefficient & St. Error & 95 Percent & C.I \\
\hline H & 0.245 & 0.004 & 0.237 & 0.233 \\
\hline MO & 0.209 & 0.003 & 0.202 & 0.26 \\
\hline A & 0.854 & 0.001 & 0.852 & 0.856 \\
\hline
\end{tabular}

Calculations are on Statistical Software STATA

10. Multidimensional Poverty for Female Headed Households and Male headed Households

As the main objective of present study is to analyze the gender poverty gap in Pakistan, so, this section serves the data analysis regarding gender poverty. To accomplish the purpose Multidimensional poverty for female headed house is calculated. Pakistan DHS data has been sorted to get the heads of households. Then female and male headed households have been segregated to get separate analysis for female and male headed households. In this section multidimensional poverty for female headed households is calculated. First deprivation of female household heads in each indicator is demonstrated.

Table (7) Deprivation of Female Headed Households in Each Indicator

\begin{tabular}{|l|l|l|l|}
\hline Indicator & Type & Weight & Deprived \% \\
\hline Year of schooling & Binary & 0.17 & 31.946 \\
\hline School Attendance & Binary & 0.17 & 10.00 \\
\hline Cooking fuel & Binary & 0.08 & 39.732 \\
\hline Floor & Binary & 0.08 & 58.929 \\
\hline Water & Binary & 0.08 & 86.161 \\
\hline Toilet & Binary & 0.08 & 73.661 \\
\hline Underweight & Binary & 0.08 & 86.607 \\
\hline Nutrition & Binary & 0.17 & 81.250 \\
\hline Assets & Binary & 0.04 & 67.411 \\
\hline Electricity & Binary & 0.04 & 16.875 \\
\hline
\end{tabular}

Calculations are on Statistical Software STATA 
Review of Economics and Development Studies, Vol. 7 (2) 2021, 287 - 298

Results shown in the table (7) reveal that highest deprivation faced by female headed households is in accessibility of electricity followed by child of head suffering from underweight problem. It is heartening that all the female household heads have minimum deprivation in education dimension because majority of them manage to complete their 5 years schooling and also minimum of them did not attend the school.

Table (8) MPI for Female and Male Headed Households

\begin{tabular}{|ll|lc|}
\hline \multicolumn{2}{|l|}{ Male Headed Household } & \multicolumn{2}{|l|}{ Female Headed Household } \\
\hline Coefficient & \multicolumn{2}{|c|}{ Coefficient } \\
\hline H & 0.263 & H & 0.28 \\
\hline Mo & 0.209 & Mo & 0.21 \\
\hline A & 0.754 & A & 0.75 \\
\hline
\end{tabular}

Calculations are based on software STATA

A comparison between female and male heads of household suggests that female headed households are slightly multidimensional poorer than their counterpart male headed households. Hence, answer of research question is given, that is, there is gender poverty gap in Pakistan.2

\section{A Comparison of Contribution of Each Indicator to Multidimensional Poverty}

\section{Table (9) Contribution of each Indicator}

\begin{tabular}{|l|l|l|}
\hline \multirow{2}{*}{ Indicator } & Female Headed & Male Headed \\
\cline { 2 - 3 } & Mo & Mo \\
\hline Years of schooling & 0.050 & 0.000 \\
\hline School attendance & 0.200 & 0.200 \\
\hline Cooking fuel & 0.100 & 0.100 \\
\hline Floor & 0.100 & 0.100 \\
\hline Water & 0.100 & 0.100 \\
\hline Toilet & 0.100 & 0.100 \\
\hline Underweight & 0.200 & 0.200 \\
\hline Nutrition & 0.100 & 0.100 \\
\hline Assets & 0.05 & 0.05 \\
\hline Electricity & 0.05 & 0.05 \\
\hline & & \\
\hline
\end{tabular}

Calculation are based on Statistical Software STATA

A comparison between multidimensional poverty contributed by each indicator shown in table suggest that only years of schooling by the family member of household head contributes more to multidimensional poverty. All other indicators contribute equally towards the multidimensional poverty.

2 It is worth noting that rural area present worse situation of Multidimensional poverty. 1.1 billion people in rural area while 0.2 billion people in urban areas live in multidimensional poverty globally (World Bank Group, 2018) 


\section{Multidimensional Poverty Index: Comparison with India}

India's poverty reduction performance is exceptionally good. If we talk of multidimensional poverty, India got along to drag out 271 million people from multidimensional poverty between 2005 06 and 2015 -16. Thus, cutting poverty rates from formidable 55 percent to decent 28 percen.. A comparison of multidimensional poverty index between Pakistan and India is portrayed in table (10).

Table 10 Comparisons MPI and Sever Poverty: India and Pakistan

\begin{tabular}{|c|c|c|c|c|c|c|c|}
\hline Region/Country & $\begin{array}{l}\text { Surve } \\
\mathrm{y}\end{array}$ & Year & MPI & $\begin{array}{l}\text { Head } \\
\text { Count }\end{array}$ & Intensity & $\begin{array}{l}\text { Number of } \\
\text { Poor People }\end{array}$ & $\begin{array}{l}\text { In sever Poverty } \\
\%\end{array}$ \\
\hline $\begin{array}{l}\text { East } \quad \text { Asia\& } \\
\text { Pacific }\end{array}$ & DHS & $2015-16$ & 0.025 & $5 \cdot 9$ & 43.1 & $117.7 \mathrm{~m}$ & \\
\hline $\begin{array}{l}\text { East Europe\& } \\
\text { Central Asia }\end{array}$ & DHS & - & 0.009 & 2.4 & 38 & $3.5 \mathrm{~m}$ & \\
\hline Latin America & - & - & 0.042 & 10.10 & 41.8 & $52.3 \mathrm{~m}$ & \\
\hline South Asia & & & 0.143 & 31.3 & 45.8 & $545.9 \mathrm{~m}$ & \\
\hline Sub - Sahara & - & - & 0.317 & 57.8 & & & \\
\hline Pakistan & DHS & $2012-13$ & 0.228 & 43.9 & 52.0 & $84,772,712$ & 24.7 \\
\hline India & DHS & $2015-16$ & 0.121 & $27 \cdot 7$ & 43.9 & $364,224,988$ & 8.6 \\
\hline
\end{tabular}

Source: OPHI, 2018

From the table (10) it can be concluded that MPI and sever poverty for India is far below than Pakistan.

\section{Conclusion}

Multidimensional poverty results suggest that 23 percent people in Pakistan suffered deprivation in, education, living standard and health services. Gendered analysis of multidimensional poverty suggests that female headed households are poorer than male headed households. Performance of India in reducing poverty is enviable.

\section{Future Research}

The analysis can further be improved by utilizing individual level information in the estimation model. Furthermore, incorporating attribute like women's empowerment in the model can translate gender gap in poverty more explicitly.

\section{References}

Abbas, A., Awan, S., Waqas, M., and Ashraf, A. (2012). Measuring the Multidimensional Poverty: A Case Study of District Sargodha

Alkire, S., \& Foster, J. (2007). Counting and multidimensional poverty. Oxford University, OPHI Working Paper 7.

Alire, S. and Kanagaratnam, U. (2018) Global Multidimensional poverty: Most etailed

Alkire, S. \& Foster, J. (2011a). Counting and Multidimensional Poverty Measurement. Journal of 
Review of Economics and Development Studies, Vol. 7 (2) 2021, 287 - 298

Public Economics, Vol. 95, Issues 7-8, pgs. 476-487.

Alkire, S. \& Foster, J. (2011b). Understandings and Misunderstandings of Multidimensional Poverty Measurement. The Journal of Economic Inequality, 9(2), 289-314.

Alkire, S. \& Jahan, S. (2018). Assessing Multidimensional Poverty - One Index at Global Level, Human Development Reports 2018, UNDP.

Alkire, S. and Kanagaratnam, U. (2018) Global Multidimensional Poverty: Most Detailed Picture to Date of the World's Poorest people. OPHI, Oxford University.

Alkire, S, and Santos, M. E. (2007). Multidimensional Poverty Index. OPHI Discussion Paper

Alkire, S. \& Santos, M.E. (2014). Measuring Acute Poverty in the Developing World: Robustness and Scope of the Multidimensional Poverty Index, World Development, 59, 251-274.

Alkire, S.. Conconi, A., and Seth, S. (2014). Brief Methological Note and Results 108 Developing Countries. OPHI, Oxford University.

Alkire, S., Foster, J., Seth, S., Santos, M. E., Roche, J. M. \&Ballón, P. (2015). Multidimensional Poverty Measurement and Analysis. Oxford: Oxford University Press.

Alkire, S , Roche, J. M., Vaz, A. (2017) Multidimensional Poverty: Methodology and Results for 34 Countris. OPHI. Oxford University.

Angulo, R., Diaz, Y. and Pardo, R. (2013) Multidimensional Poverty in Colombia, 1997 - 2010. Institute for Social and Economic Research

Atkinson, A.B. (2003). Multidimensional Deprivation: Contrasting Social Welfare and Counting Approach. Journal of Economic Inequality, Vol. 1, Issue 1, pgs. 51-65.

Batana, Y. M. (2008). Multidimensional measurement of poverty in sub-Saharan Africa. Oxford Poverty and Human Development Working Paper 13.

Batana, Y. M. (2013). Multidimensional measurement of poverty among women in Sub-Saharan Africa. Social Indicators Research, 112(2), 337-362.

Battison, D., Cruce, C., Lugo, M. A. and Santos, M. E. (2013) Income and Beyond: Multidimensional Poverty in Six Latin American Countries. Social Indicator Research, 112(2), 291- 314.

Bureau of International Information Program (2017) United States Department of State. USA

Calvi, R. (2016). Why are older women missing in India? The Age Profile of Bargaining Power and Poverty. Women and international Relation, ejournal.

Cerioli, A. and Zani, S. (1990). A Fuzzy Approach to Measurement of poverty: Income and Wealth Distribution, Inequaility and Poverty, Springer. 272 -274.

Chakravarty, S., Deutsch, J. \& Silber, J. (2008). On the Watts Multidimensional Poverty Index and its Decomposition. World Development, 36 (6). 1067-1077.

Cheli, B. and Lenmi, A. (1995) A Totally Fuzzy and Relative Approach to Multidimensional Analysis of Poverty. Economic Note 24, $115-134$.

Crawford, A., \& Evans, K. (2017). Crime prevention and community safety (pp. 797-824). Oxford University Press.

Kabubo-Mariara, J., Linderhof, V. G. M., Kruseman, G., Atieno, R., \&Mwabu, G. (2010). Povertyenvironmental links: The impact of soil and water conservation and tenure security on household welfare in Kenya. Journal of Development and Agricultural Economics, 2(1), 041053.

Espinoza-Delgado, J., \& Klasen, S. (2017). Gender and multidimensional poverty in Nicaragua: An individual-based approach (No. 235). Courant Research Centre: Poverty, Equity and Growth-Discussion Papers.

Chosal, A. (2008). Gender and Poverty: A Case Study of India. Jadavpur Journal of International Relation, 11-12(1)

Karimli, L., Samman, E., Rost, L, and Kidder, T. (2016). Factors and Norms Influencing Unpaid Care work; Household Survey: Evidence from Five Rural Communities in Colombia, 
Review of Economics and Development Studies, Vol. 7 (2) 2021, 287 - 298

Ethiopia, The Philippines, Uganda and Zimbabwe. OXAM Research Paper

Klasen, S. \& Lohti, R. (2016). How Serious is the Neglect of Intra - Household Inequality in Multidimensional Poverty Indices? Discussion paper \# 200, Courant research Center, 'Equity and Growth in Developing and Transition Countries; statistical Methods and Analysis', Georg- University Gottigen..

Lastrapes, W D., \& Rajaram, R. (2016). Gender, Caste and Poverty in India: Evidence from National Family Health Survey. Eurasian Economic Review, 6(2): 153-171

Muleta, A. N., \& Deressa, D. F. (2014). Determinants of vulnerability to poverty in female headed households in rural Ethiopia. Global Journal of Human-Social Science Research, 14(5), 9-15.

Rogan, M. (2016a). Gender and Multidimensional Poverty in South Africa: Applying the Global Multidimensional Poverty Index (MPI) Social Indicators Research, 120(3). 987-1006.

Maqsood, S., Waqas, M., and Amir, M. A. (2012) Multidimensional Measurement of Poverty in Pakistan:

Sen, A. (1976) Poverty: An Ordinal Approach to Measurement. Econometrica 44, 219 - 232.

Sethi, S., Santos, M. E., Roche, J. M., and Paola, B (2015) OPHI Working Paper No.86.

Tekgue, H. and Akbulut, B. (2019). A Multidimensional Approach to Gender Gap in Poverty: An Application for Turkey. Economy Research Institute, University of Massachusetts Amherst, Working Paper series No. 485.

Thornbeck, E. (2005). Multidimensional Poverty: Conceptual and Measurement Issues. Paper Prepared for the Many Dimensions of Poverty International Conference, UNDP International Poverty Centre, Brasilia, August 29 -31, 2005.

UNDP (2020). Multidimensional Poverty Index 2020: Charting Pathways out of Multidimensional Poverty: Achieving the SDGs 2020, Oxford University.

Vijya, R. and Lohoti, R. (2005) Moving from the Household to Individual Multidimensional Poverty Aanalysis. 


\section{Appendix}

\begin{tabular}{|c|c|c|c|c|c|c|c|c|c|}
\hline \multicolumn{10}{|c|}{ Table Comparison of poverty: India \& Pakistan } \\
\hline Country & $\begin{array}{l}\text { Year of } \\
\text { Survey }\end{array}$ & MPI & $\%$ & $\begin{array}{l}\text { Headcount } \\
2016\end{array}$ & $\begin{array}{l}\text { Intensity of } \\
\text { Deprivation }\end{array}$ & $\begin{array}{l}\text { Population } \\
\text { Vulnerable to } \\
\text { Multidimensional } \\
\text { poverty }\end{array}$ & $\begin{array}{l}\text { National } \\
\text { Poverty } \\
\text { Line } \\
2006-17\end{array}$ & $\begin{array}{l}\text { PPP\$1.90 } \\
\text { a day }\end{array}$ & $\begin{array}{l}\text { Population in sever } \\
\text { Multidimensional } \\
\text { Poverty }\end{array}$ \\
\hline India & $2015-16$ & 0.121 & $27 \cdot 5$ & 364.225 & 43.9 & 19.1 & 21.9 & 21.2 & \\
\hline Pakistan & $2012-13$ & 0.228 & 43.9 & 79.773 & 52 & 14.5 & 29.5 & 6.1 & \\
\hline
\end{tabular}

UNDP Human Development Reports 